\title{
CORRIGENDUM
}

\section{How America Supports Retirement: Challenging the Conventional Wisdom on Who Benefits. Peter J. Brady. Routledge, 2016, ISBN 1-878731-58-0, 200 pages. - CORRIGENDUM}

\section{LOUISE SHEINER}

https://doi.org/10.1017/S1474747217000385, Published by Cambridge University Press, 8 December 2017.

In the original publication of this book review the publisher of the book was listed incorrectly as Routledge. The publisher is in fact the Investment Company Institute.

\section{Reference}

Sheiner, L. (2018). How America Supports Retirement: Challenging the Conventional Wisdom on Who Benefits. Peter J. Brady. Routledge, 2016, ISBN 1-878731-58-0, 200 pages. Journal of Pension Economics and Finance, 17(1): 121-122. doi:10.1017/S1474747217000385 